\title{
Pengawetan Bambu dengan Metode Boucherie
}

\section{(Bamboo Preservation with Boucherie Method)}

\author{
Rumanintya Lisaria Putri ${ }^{1}$, Lya Rochmawati ${ }^{2}$, Dodi Nandika ${ }^{2}$, I Wayan Darmawan ${ }^{2}$
}

(Diterima April 2020/Disetujui Agustus 2020)

\begin{abstract}
ABSTRAK
Bambu adalah tanaman cepat tumbuh yang telah dimanfaatkan untuk berbagai macam produk, namun bambu rentan terhadap serangan organisme perusak. Untuk meningkatkan umur pakai maka bambu perlu diawetkan. Penelitian ini bertujuan untuk menganalisis pengaruh perbedaan struktur anatomi bambu betung (Dendrocalamus asper Backer) dan bambu andong (Gigantochloa pseudoarundinaceae (Steudel) Widjaja) dan pengaruh tekanan pada waktu alir dan retensi bahan pengawet entiblu dalam metode Boucherie. Batang bambu dengan diameter 10-14 $\mathrm{cm}$ dipotong ukuran 1; 1,5; 2 ; dan 2,5 m. Potongan bambu dengan kadar air rata-rata $30 \%$ diawetkan dengan larutan pengawet entiblu 5\% menggunakan metode Boucherie dengan tekanan 10 psi dan 15 psi. Data yang diamati adalah waktu aliran larutan pengawet entiblu dari pangkal batang sampai keluar di bagian ujung batang bambu dan retensi bahan pengawet. Struktur anatomi batang bambu sebelum diawetkan juga diamati. Hasil penelitian menunjukkan rata-rata waktu aliran larutan pengawet entiblu pada bambu andong adalah 37,75 menit, sedangkan pada bambu betung adalah 41,5 menit. Rata-rata retensi bahan pengawet entiblu pada bambu andong adalah $3,49 \mathrm{~kg} / \mathrm{m}^{3} \mathrm{dan}$ pada bambu betung adalah $3,60 \mathrm{~kg} / \mathrm{m}^{3}$.
\end{abstract}

Kata kunci: bambu andong, betung, entiblu, metode Boucherie, struktur anatomi

\section{ABSTRACT}

Bamboo is known as fast-growing species that could be derived into various products. However, bamboo is suspectible to the wood destroying organisms. Preservation is one way to improve the service life of bamboo. This study aimed to analyze the effect of differences in anatomical structures of betung bamboo (Dendrocalamus asper Backer) and andong bamboo (Gigantochloa pseudoarundinaceae (Steudel) Widjaja), and the effect of pressure on the flow time and retention of entiblu preservative in the Boucherie method. Bamboo stems with diameters of 10-14 cm were cut in $1 ; 1,5 ; 2$; and 2,5 m lengths. The bamboo stems with moisture content of around $30 \%$ were preserved by $5 \%$ of entiblu preservative solution. The data observed were the flow time of the preservative entiblu solution from base of the stem until dripping on the top of the bamboo culm, and the retention of preservative. The anatomical structure of the bamboo trunk before preserving was also observed. The results showed that the average flow times in andong bamboo and betung bamboo were 37.75 minutes and 41.50 minutes, respectively. The average retention of entiblu solution on andong bamboo was $3.49 \mathrm{~kg} / \mathrm{m}^{3}$ and on betung bamboo was $3.60 \mathrm{~kg} / \mathrm{m}^{3}$.

Keywords: andong bamboo, betung bamboo, anatomical structure, boucherie method, entiblu preservative

\section{PENDAHULUAN}

Bambu telah dikenal dan dimanfaatkan oleh masyarakat sejak dulu karena bambu adalah tanaman cepat panen dan mudah dikerjakan serta banyak ragam manfaatnya (Novrianti 2007). Pertumbuhannya yang cepat dan mudah ditanam, mendukung penyediaan bambu di masa yang akan datang. Keberadaan bambu di dunia dapat dikelompokan ke dalam 75 negara dan 1250 jenis yang tumbuh hampir di seluruh dunia (Morisco 1999) dan kebanyakan terdapat di Asia (Novrianti 2007). Wijaya et al. (2004) melaporkan bahwa terdapat 143 jenis bambu di Indonesia dan baru

1 Departemen Akutansi, Fakultas Ekonomi, Universitas Islam Balitar, JI. Majapahit No. 2-4, Sananwetan, Kec. Sananwetan, Blitar 66137

2 Departemen Hasil Hutan, Fakultas Kehutanan, Institut Pertanian Bogor, Kampus IPB Darmaga, Bogor 16680

* Pernulis Korespondensi: Email: wayandar@indo.net.id diketahui 32 jenis yang mempunyai kegunaan yang berbeda-beda. Luas tanaman bambu di Indonesia pada tahun 2000 diperkirakan mencapai 2.104.000 ha yang terdiri atas 690.000 ha dalam kawasan hutan dan 1.414.000 ha di luar kawasan hutan (FAO \& INBAR 2005). Bambu di Indonesia tersebar luas di Jawa, Sumatera, Kalimantan, Sulawesi, Bali, Maluku, dan Nusa Tenggara Timur (Novrianti 2007). Salah satu produsen pemasok kebutuhan bambu di Indonesia berasal dari Pulau Jawa. Jenis-jenis bambu yang banyak dibudidayakan di Pulau Jawa meliputi bambu ampel (Bambusa vulgaris Schrad), bambu betung (Dendrocalum asper Backer), bambu andong (Gigantochloa verticillata Willd), bambu hitam (Gigantochloa atroviolaceae Widjaja), dan bambu tali (Gigantochloa apus Schultes Kurz) (Wijaya 2001).

Bambu merupakan salah satu hasil hutan bukan kayu yang sangat penting bagi pembangunan Indonesia. Bambu banyak digunakan oleh masyarakat sebagai bahan bangunan rumah tradisional sejak dulu. 
Selain itu, bambu dimanfaatkan menjadi bahan baku produk, seperti mebel, anyaman, ukiran, perabot rumah tangga, alat musik, dan konstruksi ringan (Wijaya 2001; Rulliaty et al. 2012). Salah satu kelemahan bambu adalah keawetan alaminya rendah sehingga mudah terserang organisme perusak (Aini et al. 2009; Sulthoni 1994). Kerusakan bambu dapat disebabkan oleh perusak biologis dan non-biologis. Perusak biologis yang sering menyerang bambu adalah rayap (termite), kumbang bubuk (beetle), jamur pelapuk, jamur pewarna biru (blue stain), serta mikroorganisme laut (Lempang 2016). Berdasarkan Standar Nasional Indonesia (SNI) 01.7207-2006 kelas keawetan alami bambu andong adalah kelas awet III (sedang), sedangkan bambu betung termasuk kelas awet IV (buruk) terhadap serangan rayap kayu kering (Febrianto et al. 2014).

Salah satu cara untuk meningkatkan keawetan adalah dengan melakukan pengawetan menggunakan bahan pengawet yang bersifat racun terhadap organisme perusak, seperti rayap, jamur, atau kumbang bubuk (Abdurrohim 1996). Pengawetan bambu yang sudah dilakukan sejak dulu adalah dengan metode tradisional, seperti perendaman dalam lumpur atau dalam air mengalir. Namun demikian, proses pengawetan ini tidak efektif untuk meningkatkan keawetan bambu karena membutuhkan waktu yang lama (Muslich \& Rulliaty 2014). Metode pengawetan konvensional telah diaplikasikan untuk mengawetkan bambu melalui metode perendaman dalam larutan pengawet, seperti arsenic dan napthanate, namun menghasilkan limbah bahan beracun, bau yang menyengat, waktu pengawetan yang lama, serta menghasilkan distribusi bahan pengawet yang tidak merata (Ruslan et al. 2012). Pengawetan bambu secara konvensional, yaitu karbonisasi dan vakum tekan, juga dinilai kurang efektif. Oleh karena itu, untuk meningkatkan efektivitas pengawetan bambu tersebut maka dikembangkan teknologi pengawetan dengan metode Boucherie.

Prinsip kerja metode Boucherie adalah dengan memanfaatkan kapilaritas bambu atau dengan proses vakum tekan (Muslich \& Rulliaty 2014). Proses pengawetan dengan metode Boucherie merupakan salah satu cara pengawetan sederhana dan cocok untuk bambu segar, berukuran panjang, dan tidak perlu dibelah. Findlay (1985) menyatakan bahwa proses Boucherie terbukti sangat efektif untuk mengawetkan bambu yang masih segar dengan bahan pengawet larut air. Salah satu tujuan dalam peningkatan keawetan bambu ialah mencegah pertumbuhan jamur pada bambu. Bahan kimia yang mengandung fungisida untuk mencegah pertumbuhan jamur, baik blue stain atau jamur pelapuk pada bambu adalah entiblu. Entiblu adalah bahan pengawet larut air, berbentuk cairan suspensi yang terdiri atas bahan aktif klorotalonil (CTL) dan karbendazim (Ismanto \& Martono 2013). Penelitian pengawetan bambu menggunakan entiblu dengan metode Boucherie belum pernah dilakukan. Oleh karena itu, pada penelitian ini dilakukan pengawetan bambu betung dan bambu andong dengan metode Boucherie menggunakan bahan pengawet entiblu. Bambu betung dan bambu andong merupakan jenis bambu yang potensinya tinggi dan sering dimanfaatkan masyarakat untuk keperluan bahan konstruksi dan perabot.

Pengawetan bambu betung dan andong dengan metode tradisional dan metode konvensional dinilai kurang efektif. Metode pengawetan bambu betung dan andong dengan metode Boucherie dipertimbangkan dapat mengatasi kelemahan-kelemahan pada metode tradisional dan konvensional. Keberhasilah proses pengawetan bambu dengan metode Boucherie ditentukan berdasarkan lamanya waktu alir bahan pengawet dari pangkal batang ke ujung batang bambu, dan nilai retensi yang dihasilkan setelah pengawetan. Penelitian ini bertujuan untuk menganalisis pengaruh perbedaan struktur anatomi bambu betung (Dendrocalamus asper Backer) dan bambu andong (Gigantochloa pseudoarundinaceae (Steudel) Widjaja), dan pengaruh tekanan pada waktu alir dan retensi bahan pengawet entiblu dalam metode Boucherie.

\section{METODE PENELITIAN}

\section{Pengadaan Bahan}

Jenis bambu yang digunakan pada penelitian ini ialah bambu betung dan bambu andong yang berumur 4-5 tahun. Bambu betung diperoleh dari Desa Ciherang, di Kecamatan Dramaga, Kabupaten Bogor, sedangkan bambu andong diperoleh dari Desa Cangkurawok, Kecamatan Dramaga Kabupaten Bogor. Bahan pengawet yang digunakan adalah entiblu 450/100 SC dengan bahan aktif klorotalonil (CL) dan karbendazim, serta bahan-bahan untuk identifikasi anatomi bambu, yaitu gliserin, alkohol 30\%, 50\%, 70\%, $90 \%$, dan $96 \%$, dan safranin. Kilang pengawet Boucherie tersedia di Laboratorium Bagian Teknologi Peningkatan Mutu Kayu, Departemen Hasil Hutan, Fakultas Kehutanan, Institut Pertanian Bogor. Identifikasi anatomi bambu dilakukan melalui identifikasi herbarium kedua jenis bambu di Pusat Penelitian dan Pengembangan Hutan (Puslitbang) Bogor.

\section{Persiapan Sampel Bambu}

Bambu betung dan andong berdiameter antara 10-14 cm masing-masing sebanyak 10 batang dipilih dan ditebang serta dibersihkan dari ranting dan daundaunnya. Batang-batang bambu dipotong sepanjang 1; 1,5; 2,0; dan 2,5 m (Gambar 1). Batang bambu dibungkus plastik agar dalam kondisi segar dengan kadar air di atas 30\%.

\section{Pengamatan Struktur Anatomi}

Contoh uji untuk pengamatan struktur anatomi diambil dari batang bambu tanpa buku dengan panjang $20 \mathrm{~cm}$. Ruas bambu tanpa buku kemudian dibelahbelah selebar $3 \mathrm{~cm}$ dari masing-masing ruas bambu 
betung dan bambu andong yang masih segar (Gambar 2).

Struktur mikroskopis batang bambu diamati pada penampang lintang bambu menggunakan mikroskop cahaya. Sayatan mikrotom diambil dari bidang lintang mengikuti metode yang dikembangkan oleh Gasson et al. (2010). Sampel uji anatomi dilunakkan melalui perebusan pada air panas selama \pm 5 jam, kemudian direndam dalam larutan gliserol (alkohol : gliserin = $1: 1)$. Selanjutnya sampel uji anatomi bambu disayat dengan ketebalan 20-30 $\mu \mathrm{m}$. Sayatan tipis utuh kemudian dicuci dengan akuades, direndam dalam larutan safranin, selanjutnya didehidrasi bertingkat dengan alkohol 30, 50, 70, 90, dan 96\% masingmasing selama 5 menit. Sayatan diletakkan di atas object glass untuk selanjutnya diamati menggunakan miksroskop cahaya perbesaran 20X dan hasilnya didokumentasikan. Ciri mikroskopis yang diamati, yaitu organisasi sel-sel penyusun bambu, terutama ikatan pembuluh (vascular bundle). Ikatan pembuluh yang terdapat pada sampel dihitung jumlahnya dan diukur diameternya. Penghitungan jumlah dan dimater pembuluh dilakukan di seluruh luas penampangnya.

\section{Persiapan Bahan Pengawet}

Bahan pengawet yang digunakan adalah entiblu 450/100SC. Larutan pengawet disiapkan sebanyak 25 liter dengan konsentrasi bahan pengawet entiblu $5 \%$. Larutan pengawet yang sudah siap, kemudian dimasukkan ke dalam tangki pengawet Boucherie (Gambar 3).

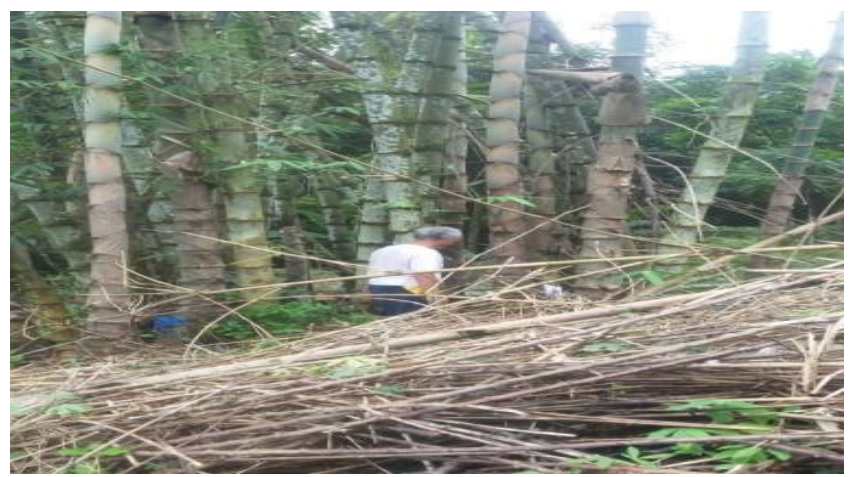

(a)

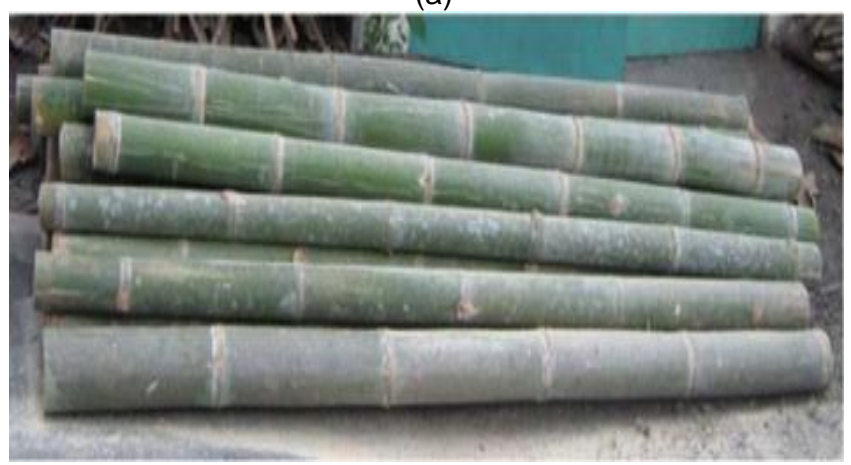

(b)

Gambar 1 a) Pemilihan batang bambu dan b) Pembersihan batang bamboo.

\section{Pengawetan Bambu dengan Metode Boucherie}

Proses pengawetan diawali dengan memasukkan larutan pengawet ke dalam tangki pengawet (Gambar 4a). Batang bambu yang masih segar ditimbang bobotnya, selanjutnya disambungkan pada nosel pipa dan diklem. Klem dikencangkan untuk mencegah kebocoran larutan pengawet (Gambar 4b). Batang-batang bambu yang sudah terpasang di nosel siap untuk diawetkan (Gambar 4c). Selanjutnya tangki udara diberi tekanan yang berbeda, yaitu 10 dan 15 psi. Kombinasi perlakuan panjang batang bambu dan tekanan diulang sebanyak 2 kali. Kran yang menuju ke tabung larutan pengawet dibuka secara perlahanlahan sehingga manometer pada tekanan menunjukkan tekanan yang diinginkan. Kran pada nosel dibuka agar larutan pengawet mengalir ke batang bambu. Cairan bambu ditunggu hingga menetes dan membasahi seluruh permukaan ujung bambu (Gambar 4d). Lama waktu yang dibutuhkan oleh cairan bahan pengawet untuk mengalir dari pangkal batang hingga menetes pada ujung batang bambu dicatat. Cairan bahan pengawet yang menetes ditampung dengan

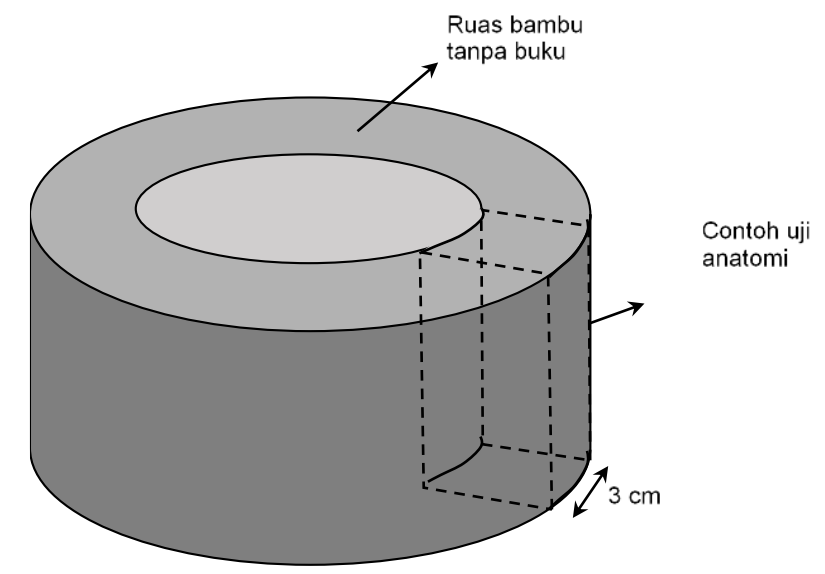

Gambar 2 Pengambilan contoh uji struktur anatomi dari batang bamboo tanpa buku

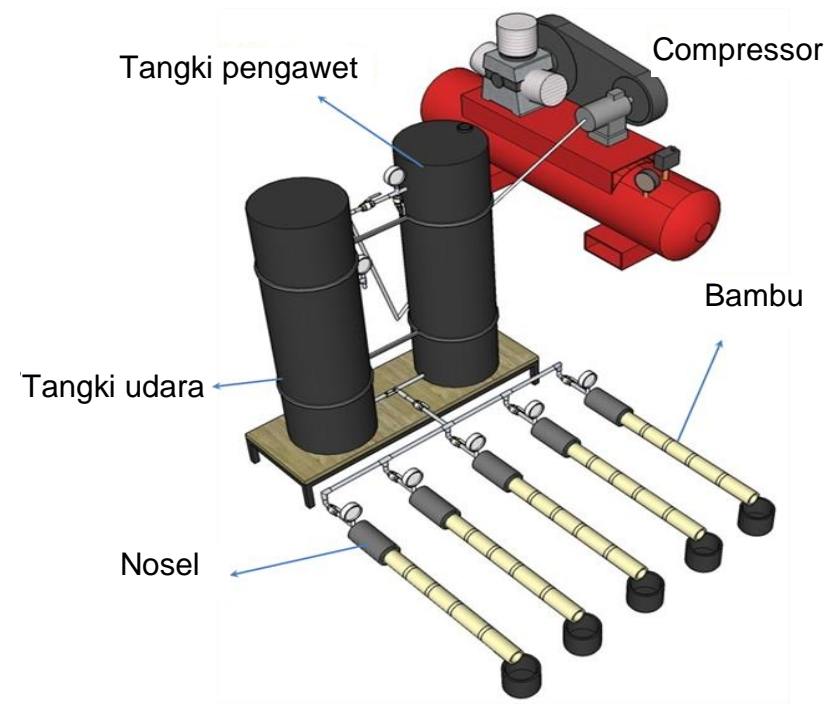

Gambar 3 Sketsa Kilang Pengawet Metode Boucherie. 


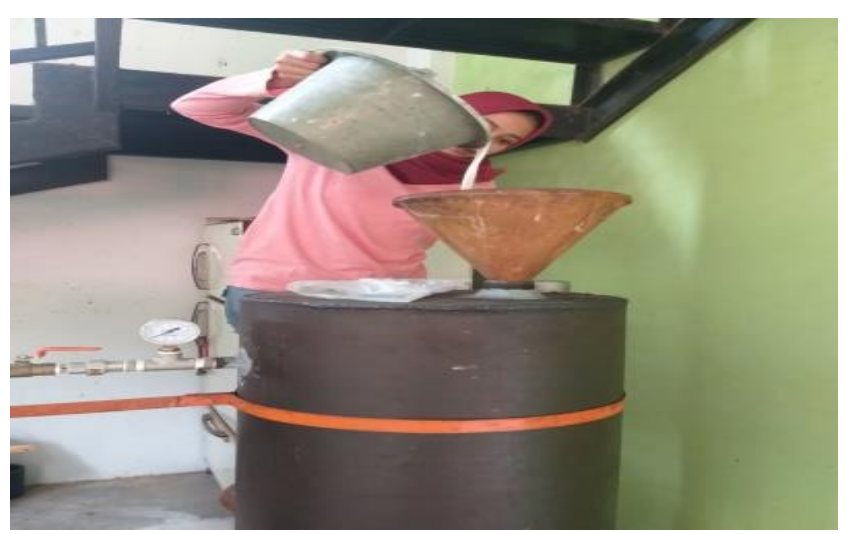

(a)

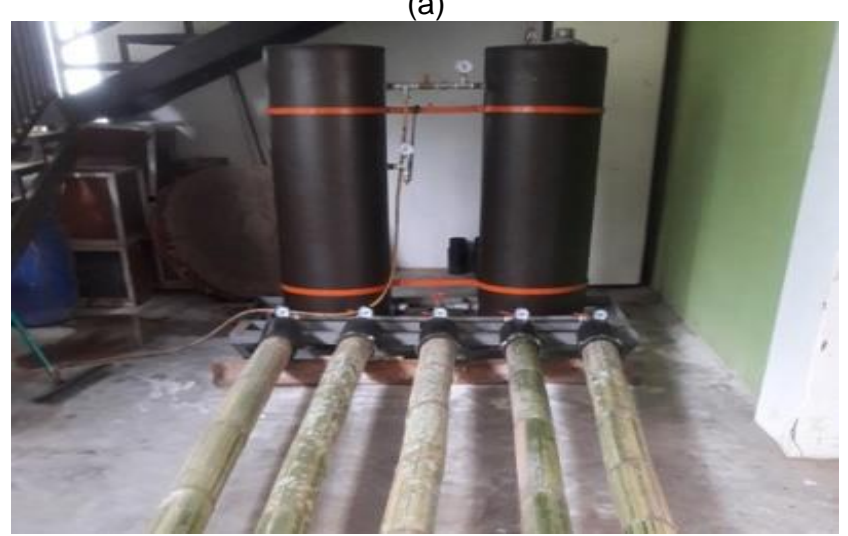

(c)

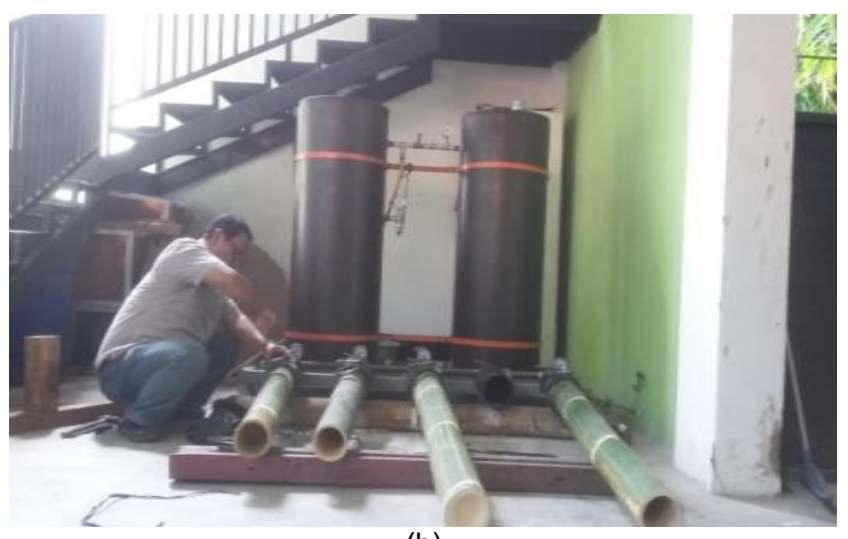

(b)

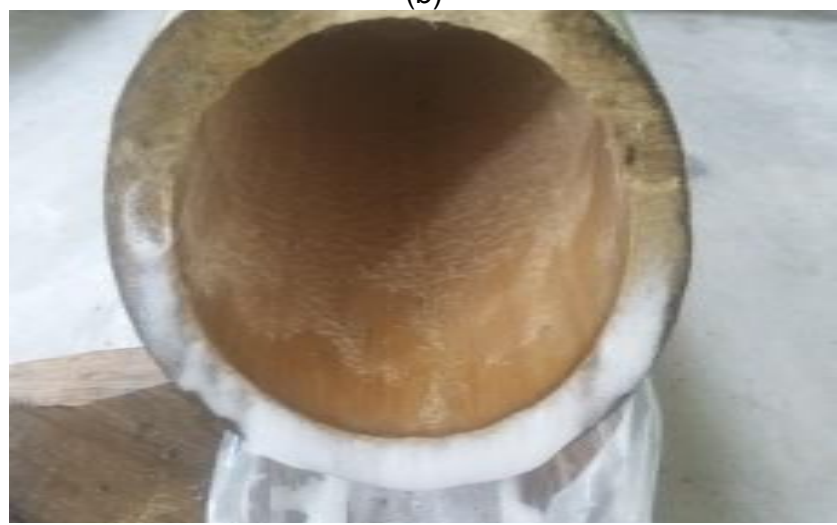

(d)

Gambar 4 Tahapan proses pengawetan bambu dengan metode Boucherie: a) Pemasukan larutan pengawet ke dalam tangki pengawet; b) Pemasangan batang bambu ke dalam nosel; c) Batang-batang sudah terpasang dan siap dialiri larutan bahan pengawet; d) Larutan larutan bahan pengawet telah meresap dan menetes pada bagian ujung bambu.

gelas erlenmeyer. Bambu yang sudah diawetkan kemudian dilepaskan dari nosel dan ditimbang bobotnya.

Nilai retensi bahan pengawet dihitung menggunakan rumus (Hunt \& Garratt 1986):

$$
R=\frac{B_{1}-B_{0}}{V} \times \mathrm{K}
$$

\section{Keterangan:}

$\mathrm{R}=$ Retensi bahan pengawet $\left(\mathrm{kg} / \mathrm{m}^{3}\right)$

$B_{1} \quad=$ Bobot batang bambu setelah pengawetan $(\mathrm{kg})$

$B_{0}=$ Bobot batang bambu sebelum pengawetan $(\mathrm{kg})$

$\mathrm{V}=$ Volume batang bambu $\left(\mathrm{m}^{3}\right)$

$\mathrm{K}=$ Konsentrasi larutan bahan pengawet (\%)

\section{Analisis Data}

Analisis keragaman terhadap lama waktu serap dan retensi mengunakan model percobaan faktorial dalam blok dengan 2 faktor, yaitu faktor jenis bambu (bambu betung dan bambu andong) dan tekanan (10 dan 15 psi), dan sebagai blok, yaitu panjang batang bambu (1; $1,5 ; 2 ; 2,5 \mathrm{~m})$.

Model umum rancangan yang digunakan adalah sebagai berikut (Montgomery 1984):

$$
Y i j k=\mu+\alpha_{i}+\beta_{j}+(\alpha \beta)_{i j}+\gamma_{k}+\varepsilon_{i j k}
$$

Keterangan:

Yijk = Nilai respons karena jenis bambu ke-i dan faktor tekanan ke-j pada blok ke-k

$\mu=$ Nilai rataan umum pengamatan

$\alpha i=$ Pengaruh faktor jenis bambu pada taraf ke-i

$\beta \mathrm{j}=$ Pengaruh faktor tekanan pada taraf ke-j

$(\alpha \beta)_{i j}=$ Pengaruh interaksi antara jenis bambu dan tekanan

$\mathrm{\gamma k}=$ Pengaruh blok pada $\mathrm{k}$

$\mathrm{i} \quad=$ Jenis bambu betung dan bambu andong

$\mathrm{j}=$ Tekanan 10 dan $15 \mathrm{psi}$

$\mathrm{k}=$ Panjang bambu $1 ; 1,5 ; 2 ;$ dan $2,5 \mathrm{~m}$

$\varepsilon i j k=$ Pengaruh galat karena faktor jenis bambu ke-i dan tekanan ke-j pada blok ke-k .

\section{HASIL DAN PEMBAHASAN}

\section{Stuktur Anatomi}

Struktur anatomi batang bambu bisa berperan penting dalam mengontrol mudah tidaknya bahan pengawet masuk ke dalam bambu karena sifat anatomi menentukan porositas dan permeabilitas batang bambu. Struktur anatomi pada bagian melintang bambu sebagian besar terdiri atas ikatan pembuluh 
dan parenkim. Salah satu bagian struktur anatomi yang berpengaruh dalam proses pengawetan adalah pembuluh metaksilem dan phloem yang terdapat pada ikatan pembuluh (Liese 1998). Dwijoseputro (1980) menyatakan bahwa metaksilem dan phloem merupakan pipa yang berhubungan satu dengan lainnya dan merupakan pipa kapiler sebagai jalan masuknya larutan bahan pengawet ke dalam bambu. Liese (1980) menyatakan bahwa pengawetan dengan metode Boucherie ideal diterapkan pada bambu karena sel-sel pembuluhnya berorientasi aksial, tidak memiliki sel-sel radial, seperti pada kayu.

Gambar 5 mengindikasikan bahwa anatomi batang bambu betung dan bambu andong memiliki struktur yang sama. Hasil penelitian menunjukkan bahwa diameter ikatan pembuluh pada bambu betung adalah sebesar 0,81 $\mathrm{mm}$, sedangkan pada bambu andong adalah $0,82 \mathrm{~mm}$. Hasil tersebut tidak jauh berbeda dari hasil penelitian Augistyra (2012) yang menyatakan bahwa diameter rata-rata ikatan pembuluh bambu betung adalah sebesar 0,84, sedangkan pada bambu andong adalah sebesar $0,87 \mathrm{~mm}$. Selain itu, bambu betung memiliki rata-rata frekuensi ikatan pembuluh/ $\mathrm{mm}^{2}$ pada bagian dekat kulit sebesar 6,33 , bagian tengah sebesar 3,67, dan pada bagian dalam sebesar 4,67. Bambu andong memiliki rata-rata frekuensi ikatan pembuluh/mm² pada bagian kulit sebesar 5,00 , pada bagian tengah sebesar 4,67 , dan pada bagian dalam sebesar 4,67.

Berdasarkan sifat anatominya, bambu dibagi ke dalam tipe ikatan pembuluh yang berbeda antara yang satu dengan lainnya. Gambar 5 menunjukkan bahwa jumlah ikatan pembuluh kedua bambu semakin ke arah dalam semakin sedikit. Grosser \& Liese (1971) menyatakan bahwa tipe ikatan pembuluh pada bambu betung dan bambu andong ialah tipe III dan IV. Ruas bambu betung dan bambu andong pada bagian tengah didominasi oleh tipe vascular bundle IV, tetapi sebagian kecil terdapat ikatan pembuluh tipe III (Augistyra 2012; Nuriyatin 2012).

Selain struktur anatomi batang bambu, kadar air juga memiliki peran penting dalam proses pengawetan dengan metode Boucherie. Semakin tinggi kadar air dalam bambu akan semakin mempercepat masuknya larutan bahan pengawet dan mempermudah proses difusi cairan pengawet. Ruliatty et al. (2012) menyatakan bahwa rendahnya kadar air bambu memengaruhi proses pengawetan karena dapat mengurangi permeabilitas bambu terhadap cairan yang masuk. Kadar air bambu yang rendah menyebabkan pengendapan bahan kimia dan dapat menutup pembuluh pada bambu (Muslich \& Rulliaty 2014). Bambu yang memiliki kadar air rendah tidak efektif bila diawetkan dengan cairan bahan pengawet.

\section{Waktu Alir Bahan Pengawet}

Waktu alir bahan pengawet adalah waktu yang dibutuhkan bahan pengawet untuk mengalir dari pangkal batang sampai ke ujung batang bambu. Bambu betung yang diawetkan mengandung kadar air rata-rata $32 \%$ dan bambu andong mengandung kadar air rata-rata sebesar 33\%. Kadar air pada batang bambu sedikit bervariasi menurut jenis, posisi dalam batang, dan umur batang bambu. Bambu yang sudah berumur lebih dari tiga tahun umumnya mengalami penurunan kadar air. Batang bambu muda mengalami penurunan kadar air berkisar antara $50-90 \%$, sedangkan bambu tua berkisar antara 12-18\% (Dransfield \& Widjaja 1995).Rata-rata waktu alir bahan pengawet pada bambu betung ukuran $1 ; 1,5 ; 2,0$; dan $2,5 \mathrm{~m}$ pada tekanan 10 psi berturut-turut adalah sebesar 26,5; 38,0; 43,5; dan 74,0 menit, sedangkan pada tekanan

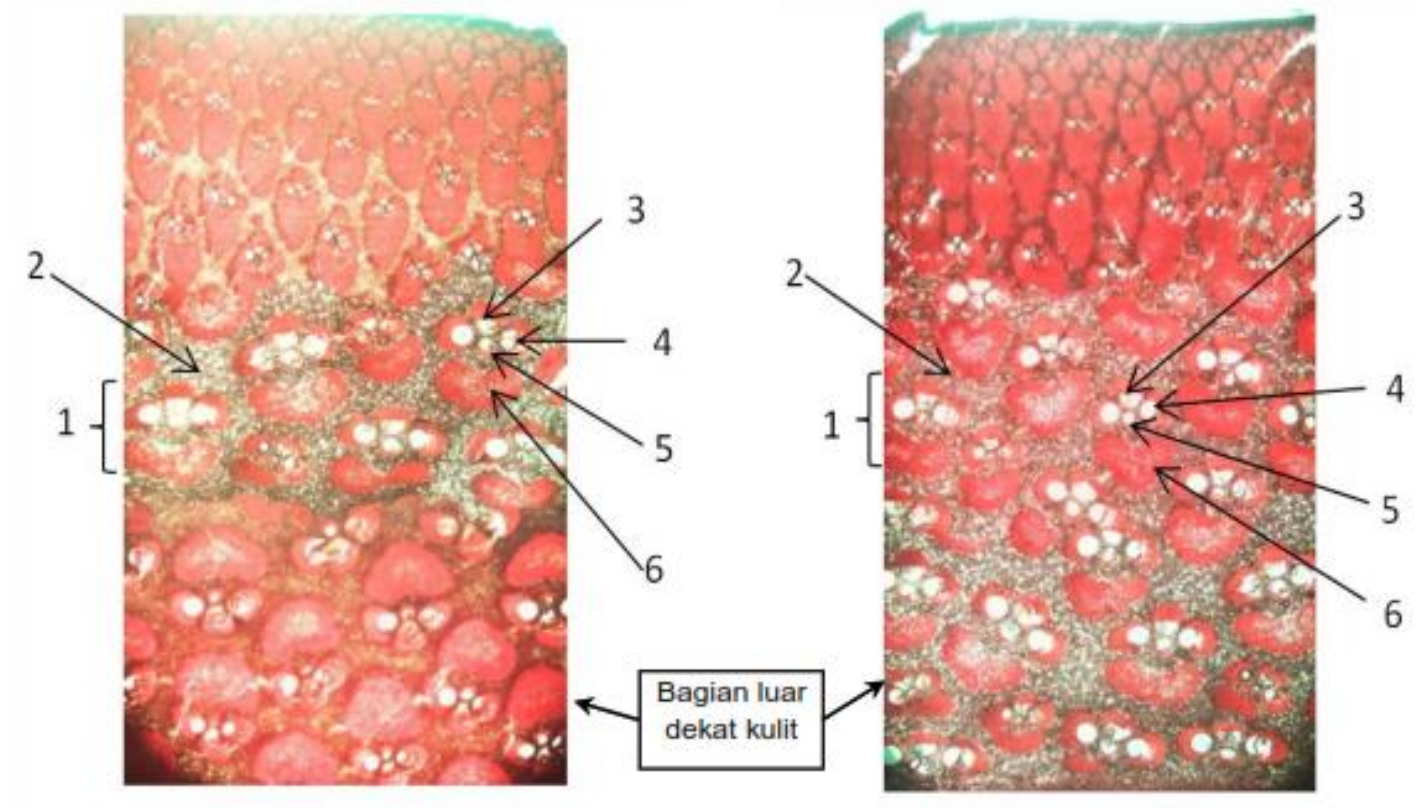

Gambar 5 a) Struktur anatomi batang bambu betung dan b) Bambu andong. $1=$ Ikatan pembuluh; 2 = Parenkim; $3=$ Jaringan floem; 4 = Pembuluh metaksilem; 5 = Ruang antar sel; 6 = Rantai serabut. 
15 psi berturut-turut adalah sebesar 20,0;30,0;38,5; dan 59,5 menit (Gambar 6). Selanjutnya rata-rata waktu alir bahan pengawet pada bambu andong ukuran $1 ; 1,5 ; 2$; dan $2,5 \mathrm{~m}$ pada tekanan $10 \mathrm{psi}$ berturut-turut adalah sebesar 23,0; 32,0; 41,5; dan 64,5 menit, sedangkan pada tekanan 15 psi berturut-turut adalah sebesar 21,$5 ; 29,0 ; 36,5$; dan 54,0 menit. Hasil ini memperlihatkan bahwa kemampuan bahan pengawet berdistribusi dari pangkal ke ujung cukup bervariasi. Waktu yang dibutuhkan oleh bahan pengawet entiblu untuk mendistribusikan secara efektif bahan pengawet dari pangkal hingga ujung bambu dengan ukuran panjang 2,5 m sekitar 74,00 menit. Hasil ini mengindikasikan bahwa pengawetan bambu dengan metode Boucherie jauh lebih efektif dari segi waktu dibandingkan dengan pengawetan metode tradisional ataupun konvensional dengan perendaman yang membutuhkan waktu kurang lebih 1 bulan (Handoko et al. 2015).

Hasil analisis keragaman (tingkat nyata $5 \%$ ) pada Tabel 1 menunjukkan bahwa jenis bambu tidak berpengaruh nyata pada waktu alir, namun tekanan berpengaruh nyata pada waktu alir. Waktu alir tidak berbeda nyata antara kedua jenis bambu disebabkan karena kedua jenis bambu memiliki stuktur anatomi yang hampir sama. Besar tekanan berpengaruh nyata pada waktu alir disebabkan karena adanya perbedaan kecepatan aliran bahan pengawet karena perbedaan tekanan yang diberikan. Semakin tinggi tekanan, maka kecepatan aliran larutan pengawet akan semakin tinggi sehingga waktu alir akan semakin singkat. Waktu alir bahan pengawet tercepat, yaitu 21,50 menit, terjadi pada bambu andong panjang $1,0 \mathrm{~m}$ dengan tekanan 15 psi dan waktu alir terlama, yaitu 74,00 menit, terjadi pada bambu betung dengan panjang $2,5 \mathrm{~m}$ pada tekanan 10 psi. Susanti (2001) juga melaporkan bahwa pada pengawetan bambu wulung dengan metode Boucherie, waktu alir bahan pengawet dipengaruhi secara nyata oleh kadar air dan kecepatan aliran bahan pengawet.

\section{Retensi}

Retensi adalah banyaknya bahan pengawet yang masuk dan tertinggal dalam bahan yang diawetkan, yang dinyatakan dalam bobot bahan pengawet per unit volume bahan yang diawetkan (Tobing 1977). Salah satu indikator efektivitas pengawetan adalah mengetahui retensi cairan pengawet yang masuk ke dalam bambu. Nilai retensi bambu dengan metode Boucherie pada penelitian ini dihitung pada saat pengawet sudah meresap dan menetes hingga ujung bambu. Rata-rata retensi bahan pengawet pada kedua jenis bambu dengan tekanan yang berbeda disajikan pada Gambar 7. Rata-rata retensi bahan pengawet

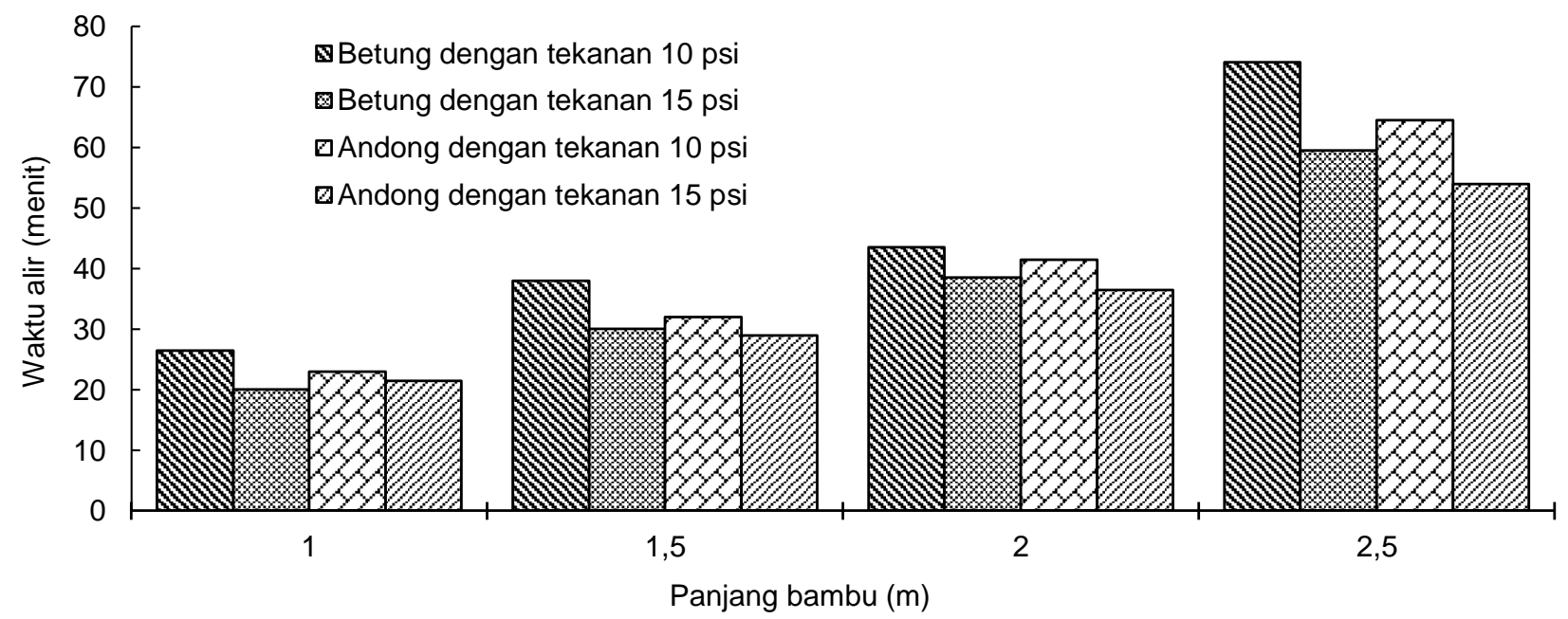

Gambar 6 Waktu alir larutan bahan pengawet dengan metode Boucherie pada tekanan 10 dan 15 psi pada bambu betung dan bambu andong.

Tabel 1 Hasil analisis keragaman pada waktu alir larutan pengawet pada bambu betung dan andong dengan tekanan 10 dan 15 psi

\begin{tabular}{lcrrr}
\hline \multicolumn{1}{c}{ Source } & DF & Sum of squares & Mean squares & $\mathrm{F}$ \\
\hline Jenis bambu & 1 & 42,71 & 42,71 & 4,62 \\
Tekanan & 1 & 166,73 & 166,73 & 18,05 \\
Blok panjang bambu & 3 & 3477,27 & 1159,09 & 125,49 \\
Jenis bambu*Tekanan & 1 & 11,73 & 1,73 & 1,27 \\
Error & 8 & 73,88 & 0,00 & 0,29 \\
Corrected total & 14 & 3763,73 & 9,23 & \\
\hline
\end{tabular}


pada bambu betung ukuran $1 ; 1,5 ; 2,0$; dan $2,5 \mathrm{~m}$ pada tekanan 10 psi secara berturut-turut adalah sebesar 3,$36 ; 3,88 ; 3,77$; dan $2,23 \mathrm{~kg} / \mathrm{m}^{3}$, sedangkan pada tekanan 15 psi berturut-turut adalah sebesar 5,08; 3,63; 4,08; dan 2,59 kg/m³ (Gambar 7). Selanjutnya, rata-rata retensi bahan pengawet pada bambu andong ukuran panjang $1 ; 1,5 ; 2,0$; dan $2,5 \mathrm{~m}$ pada tekanan 10 psi secara beturut-turut adalah sebesar 4,48; 4,36; 2,95, dan $2,41 \mathrm{~kg} / \mathrm{m}^{3}$, sedangkan pada tekanan $15 \mathrm{psi}$ berturut-turut adalah sebesar 4,14; 3,51; 3,30; dan 2,81 $\mathrm{kg} / \mathrm{m}^{3}$. Hasil ini mengindikasikan bahwa semakin panjang batang bambu, semakin rendah retensi bahan pengawet yang dihasilkan, meskipun cairan bahan pengawet sama-sama telah menetes pada bagian ujung bambu.

Hasil analisis keragaman pada taraf nyata 5\% menunjukkan bahwa faktor jenis bambu dan tekanan tidak berpengaruh nyata pada nilai retensi bahan pengawet (Tabel 2). Menurut Sulthoni (1985) bahwa absorbsi bahan pengawet (retensi) dipengaruhi oleh beberapa faktor, seperti konsentrasi bahan pengawet, lama pengawetan, sifat bahan kimia yang digunakan, umur, dimensi bambu, dan kadar air. Retensi pada bambu betung dan bambu andong belum memenuhi standard SNI 01-5010-1-1999 (BSN 2003) mengenai pengawetan kayu untuk perumahan dan gedung karena minimal retensi bambu untuk dijadikan konstruksi adalah $8,00-11,60 \mathrm{~kg} / \mathrm{m}^{3}$. Dengan demikian dapat disarankan untuk dikembangkan suatu model yang dapat memperkirakan besarnya retensi yang diinginkan dengan lamanya waktu pengawetan.

Meskipun retensi bahan pengawet yang dihasilkan belum memenuhi ambang batas untuk dimanfaatkan sebagai bahan konstruksi, pengawetan bambu dengan metode Boucherie terbukti menghasilkan retensi yang tinggi dibandingkan dengan metode perendaman (Wardiha et al. 2018). Penelitian yang dilakukan Hamzah et al. (2016) pada bambu betung ukuran $7 \times 3$ $\mathrm{cm}$ yang diawetkan dengan metode perendaman selama 72 jam dengan bahan pengawet boraks hanya menghasilkan retensi sebesar $0,0097 \mathrm{~kg} / \mathrm{m}$. Muslich \& Rulliaty (2014) dalam Susanti (2001) menyatakan bahwa metode Boucherie lebih efektif karena memanfaatkan pembuluh kapiler bambu dalam arah longitudinal. Besarnya retensi pada proses pengawetan dengan metode Boucherie dapat ditingkatkan dengan menambah waktu pengawetan atau memperbesar konsentrasi bahan pengawet (Darupratomo 2008).

\section{KESIMPULAN}

Waktu alir bahan pengawet tidak dipengaruhi oleh jenis bambu, namun dipengaruhi oleh besarnya tekanan. Rata-rata waktu alir bahan pengawet entiblu pada bambu andong adalah 37,75 menit, sedangkan pada bambu betung adalah 41,5 menit. Waktu alir tercepat, yaitu 21,5 menit, ditemukan pada bambu

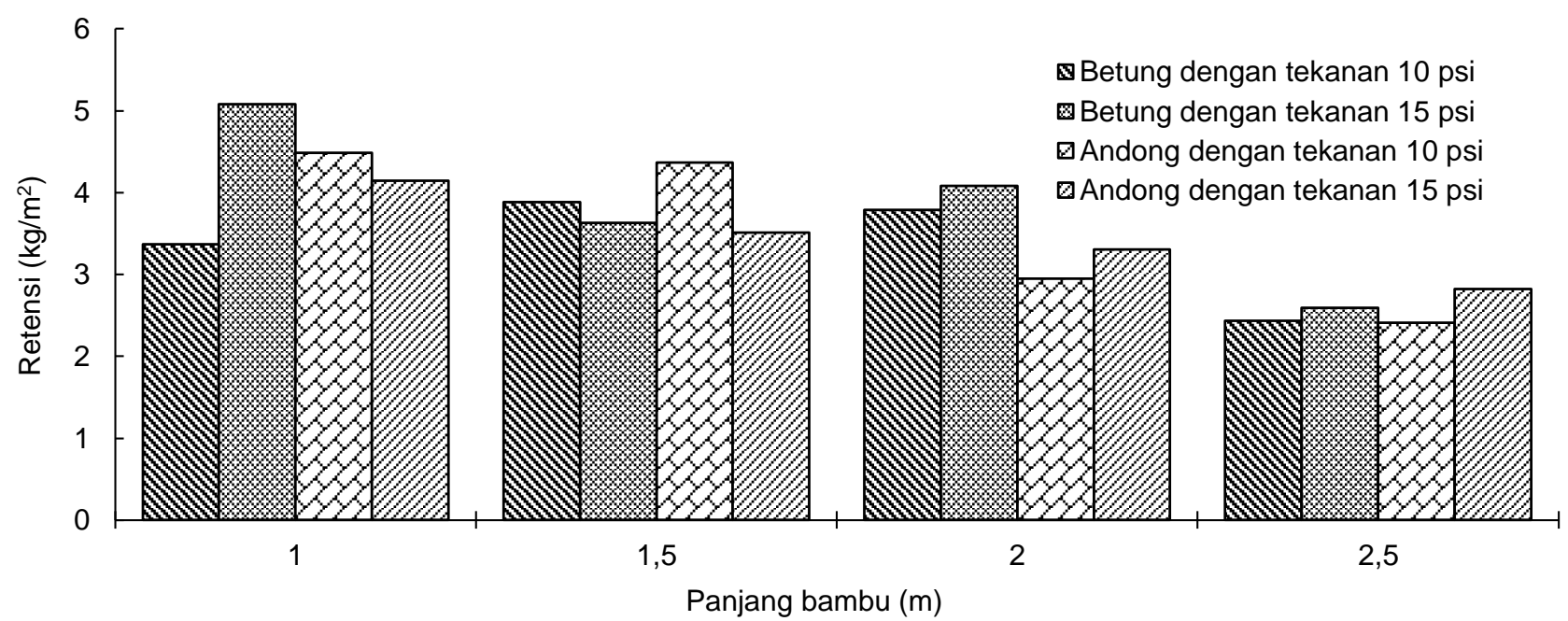

Gambar 7 Retensi bahan pengawet dengan metode Boucherie pada tekanan 10 dan 15 psi pada bambu betung dan bambu andong.

Tabel 2 Hasil analisis keragaman pada retensi larutan pengawet pada bambu betung dan andong dengan tekanan 10 dan 15 psi

\begin{tabular}{|c|c|c|c|c|c|}
\hline Source & $D F$ & Sum of squares & Mean squares & $\mathrm{F}$ & $\mathrm{Pr}>\mathrm{F}$ \\
\hline Model & 6 & 6,50 & 1,08 & 4,21 & 0,03 \\
\hline Jenis bambu & 1 & 0,12 & 0,12 & 0,49 & 0,50 \\
\hline Tekanan & 1 & 0,04 & 0,04 & 0,15 & 0,70 \\
\hline Blok panjang bambu & 3 & 6,02 & 2,00 & 7,81 & 0,00 \\
\hline Jenis Bambu*Tekanan & 1 & 0,50 & 0,50 & 1,95 & 0,19 \\
\hline Error & 8 & 2,05 & 0,25 & & \\
\hline Corrected Total & 14 & 8,56 & & & \\
\hline
\end{tabular}


andong panjang $1 \mathrm{~m}$ dengan tekanan 15 psi dan waktu terlama, yaitu 74,00 menit, ditemukan pada bambu betung dengan panjang $2,5 \mathrm{~m}$ pada tekanan 10 psi. Nilai retensi tidak dipengaruhi oleh faktor jenis bambu dan besarnya tekanan. Rata-rata retensi bahan pengawet entiblu pada bambu andong adalah sebesar $3,49 \mathrm{~kg} / \mathrm{m}^{3}$ dan pada bambu betung adalah sebesar $3,60 \mathrm{~kg} / \mathrm{m}^{3}$. Nilai retensi paling tinggi terjadi pada bambu betung panjang 1,0 $\mathrm{m}$ dengan tekanan $15 \mathrm{psi}$, yaitu sebesar $5,08 \mathrm{~kg} / \mathrm{m}^{3}$ dan nilai terendah, yaitu 2,41 $\mathrm{kg} / \mathrm{m}^{3}$, ditemukan pada bambu andong pada panjang 2,5 m dengan tekanan 10 psi. Pengawetan bambu dengan metode Boucherie terbukti menghasilkan waktu pengawetan yang lebih singkat dan retensi yang tinggi dibandingkan dengan metode pengawetan konvensional melalui perendaman. Dapat disarankan untuk dikembangkan suatu model yang dapat memperkirakan besarnya retensi yang diinginkan sesuai standar dengan lamanya waktu pengawetan menggunakan metode Boucherie.

\section{DAFTAR PUSTAKA}

Abdurrohim S. 1996. Pengawetan lima jenis kayu secara pelaburan memakai dua jenis bahan pengawet. Buletin Penelitian Hasil Hutan. 14(5): 204-210.

Aini N, Morisco, Anita. 2009. Pengaruh pengawetan terhadap kekuatan dan keawetan produk laminasi bambu. Forum Teknik Sipil No. XIX. Bandung (ID): Balai Bahan Bangunan Puslitbang Permukiman. hlm : 979

Augistyra DD. 2012. Distribusi Ikatan Pembuluh, Sifat Fisis Mekanis Dan Bambu Laminasi Dua lapis. [Skripsi]. Bogor (ID): IPB press.

[BSN] Badan Standardisasi Nasional. 2003. Pengawetan kayu untuk perumahan dan gedung. SNI (Standar Nasional Indonesia SNI.01-50101999. Jakarta (ID): Badan Standardisasi NasionalBSN

[BSN] Badan Standardisasi Nasional. 2006. Standar Nasional Indonesia. Uji ketahanan kayu dan produk kayu terhadap organisme perusak kayu. SNI 01.7207-2006. Jakarta (ID): Badan Standardisasi Nasional-BSN

Darupratomo MT. 2008. Pengaruh Proses Pengawetan Bambu Terhadap Karakteristik Bambu Sebagai Bahan Bangunan. Prospect. 4(6): 7-20

Dransfield S, Widjaja EA. 1995. Plant Resources of South East Asia (PROSEA) No.7: Bamboos. Leiden (NL): Backhuys Publisher.

Dwijoseputro D. 1980. Pengantar fisiologi tumbuhan. Jakarta (ID). PT.Gramedia.

FAO, INBAR. 2005. Global Forest Resources Assessement Update 2005. Indonesia Country
Report on Bamboo Recources. Forest Resources Assessment Programme Working Paper (Bamboo). Food and Agriculture Organization of United Nation (FAO), Fores Department and International Network for Bamboo and Rattan (INBAR), Jakarta (ID), May, 2005.

Febrianto F, Gumilang A, Carolina, Yoresta FS. 2014. Distribusi bahan pengawet larut air pada kayu diawetkan secara sel penuh dan sel kosong. Jurnal Ilmu dan Teknologi Kayu Tropis. 12(1): 20-32.

Findlay WPK. 1985. Preservation of timber in the tropics. Dodrecht, Netherlands (NL). Kluwer Academic Publisher. https://doi.org/10.1007/97894-017-2752-5

Gasson P, Miller R, Stekel DJ, Whinder F, Zieminska K. 2010. Wood identification of Dalbergia nigra (CITES Appendix I) using quantitave wood antomy, principal components analysis and naive Bayes classification. Journal Annals of Botany. 105: 45-56. https://doi.org/10.1093/aob/mcp270

Grosser D, Liese W. 1971. On the anatomy of Asian bamboo, with special reference to their vascular bundles. Wood Science Technology. 5: 290-312. https://doi.org/10.1007/BF00365061

Handoko EB, Maurina A, Gustin R, Sudira B, Priscila J. 2015. Peningkatan durabilitas bambu sebagai komponen konstruksi melalui desain bangunan dan preservasi material. Bandung (ID). Lembaga Penelitian dan Pengabdian kepada Masyarakat Universitas Katolik Parahyangan

Hamzah N, Pujirahayu N, Tama SR. 2016. Pemanfaatan Boraks Untuk Pengawetan Bambu Betung (Dendrocalamus Asper Backer) Terhadap Serangan Rayap Tanah (Captotermes Curvignathus). Ecogreen Journal. 2: 131-136.

Hunt GM, Garratt AG. 1986. Wood Preservation. New York (US): Mc Graw - Hill Book Company.

Ismanto A, Martono D. 2013. Aktivitas fungisida bahan pengawet kayu berbahan aktif majemuk terhadap jamur biru Diplodia sp. Jurnal Sains Natural Universitas Nusa Bangsa. 3(2): 146-153. https://doi.org/10.31938/jsn.v3i2.64

Lempang M. 2016. Pengawetan bambu untuk barang kerajinan dan mebel dengan metode tangki terbuka. Info Teknis Eboni. 13(2): 79-92

Liese W. 1980. Preservation of Bamboo, in Lessard, G and Chouinard, A., Singapore. Bamboo research in asia Proceedings Workshop. May 28-30

Liese W. 1998. The anatomy of bamboo culms. Technical report: [INBAR] International Network for Bamboo and Rattan. Beijing, China (CN).

Montgomery DC. 1984. Design and Analysis of Experiments. New York (US): John Wiley \& Sons. 
Morisco B. 1999. Rekayasa Bambu. Yogyakarta (ID): Nafiri Offset.

Muslich M, Rulliaty S. 2014. Ketahanan bambu petung (Dendrocalamus asper Backer) yang diawetkan dengan CCB terhadap serangan penggerek di laut. Jurnal Penelitian Hasil Hutan. 32(3): 199-208. https://doi.org/10.20886/jphh.2014.32.3.199-208

Nuriyatin N. 2012. Pola Ikatan Pembuluh Bambu Sebagai penduga Pemanfaatan Bambu [Skripsi]. Bogor (ID). IPB Press.

Novrianti E. 2007. Pengaruh morfologi batang bambu terhadap efisiensi penebangan. Info Hasil Hutan. 30 (1): 1-16.

Rulliaty S, Muslich M, Hadjib N, Pari G, Basri E, Sulastiningsih IM. 2013. Sifat Dasar dan Kegunaan Bambu. Bogor (ID). Laporan Hasil Penelitian Pusat Penelitian dan Pengembangan Keteknikan Kehutanan dan Pengolahan Hasil Hutan.

Ruslan, Daud M, Muin M, Latief L, Firmanti A. 2012. Efektivitas Pengawetan Bambu menggunakan boron Dengan Metide Pompa Tekan Modified
Boucherie (MOBURI). Makassar (ID). Balai Pengembangan Teknologi Perumahan Tradisional.

Sulthoni A. 1994. Permasalahan Sumber Daya Bambu di Indonesia. Bogor (ID). Yayasan Bambu Lingkungan Lestari.

Susanti E. 2001. Pengawetan bambu tali (Gigantochloa apus Kurz) dengan menggunakan metode Boucherie. [Skripsi]. Bogor (ID): Institut Pertanian Bogor,

Tobing TL. 1977. Pengawetan Kayu. Bogor (ID). Lembaga Kerjasama Fakultas Kehutanan IPB.

Wardiha MW, Agistiningtyas RS, Sumawa WAM. 2018. Efektivitas pengawetan bambu petung dan gewang menggunakan boron dan ccb secara rendaman dingin boucherie yang dimodifikasi. Jurnal Penelitian Hasil Hutan. 36 (2): 159-170. https://doi.org/10.20886/jphh.2018.36.2.159-170

Wijaya EA, Utami NW, Saefudin. 2004. Panduan Membudidayakan Bambu. Bogor (ID). LIPI.

Wijaya EA. 2001. Identifikasi Jenis Jenis Bambu di Jawa. Bogor (ID): LIPI Seri Panduan Lapangan. 